\title{
Alternative Industrial Fuels in Indonesia from Urban Waste Treatment Using the RDF Method Through
}

\section{Bio-drying}

\author{
Albert Yansen ${ }^{1 *}$ \\ ${ }^{I}$ Fakultas Ekonomi, STIE Bhakti Pembangunan Jakarta, Indonesia \\ *Corresponding author. Email: albert.yansen@gmail.com
}

\begin{abstract}
This study examines the potential for RDF production from a mixture of municipal solid waste (MSW) using bio-drying technology to be used as an alternative fuel industry in Indonesia. The most suitable waste for the production of the RDF method is waste that has a high carbon content after being separated from recyclable waste. This bio-drying method is usually carried out by an aerobic process. The advantage of the bio-drying process is that it reduces waste mass and emissions of $\mathrm{CH} 4, \mathrm{CO} 2, \mathrm{SO} 2, \mathrm{NOX}$, and dust emissions from landfill waste into the atmosphere. An economic model for the use of RDF in the Indonesian industry, especially the cement plant, has been created. This model produces RDF material as an alternative fuel to replace coal which is currently used. The cost analysis carried out will result in economic savings and is environmentally friendly and can be used for other industrial fuels. In this study, urban waste that is processed into RDF is 120 tons/day. Research shows that adding $58 \%$ RDF as a substitute fuel, equivalent to 70 tons/day of fuel used in a cement kiln would save $70 \mathrm{USD} /$ day in petcoke costs with 65.8 tons/h of CO2 being emitted into the atmosphere. The bio-drying process allows a decrease in the wastewater content of up to $59 \%$ and an increase in the calorific value of the waste (LHV) by $600 \%(14.55 \mathrm{MJ} / \mathrm{kg})$, as a result of the decrease in the wastewater content.
\end{abstract}

\section{Keywords: Alternative Fuel, Bio-drying, Municipal Solid Waste, Refuse Derived Fuel (RDF).}

\section{INTRODUCTION}

Along with population growth and the development of urban economic activities, its influence will have an impact on the urban environment especially urban waste, so this must be accompanied by an increase in waste management facilities and infrastructure so that it can be fulfilled again. According to the National Waste Management Information System (SIPSN, August 2021), Indonesia has a pile of household and household-like waste of 33.42 million tons per year, of which managed waste is $62.39 \%$, unmanaged waste is $62.39 \% 37.61 \%$, and the largest type of waste is food waste by $39.8 \%$ [1],[2]. Collective sewage systems are essential for controlling environmental damage from the release of untreated waste residues. In Indonesia, municipal solid waste, comes from various sources such as household activities, commercial areas, and public facilities) is high moisture content and about 75 percent is biodegradable and cannot be readily incinerated [3]. It is estimated that only about $60 \%$ of waste in big cities in Indonesia can be transported to an Integrated Waste Management (Tempat Pengolahan Sampah Terpadu-TPST), whose main operation is landfill [4]. Illegal open dumping remains the most common form of disposal in the country (90\%), causing leachate that contaminates groundwater and contributes to the proliferation of pests and diseasecarrying pathogens. Some of the uncollected waste is burned, adding to urban air pollution, while others will clog rivers and canals, exacerbate flooding and cause the spread of contaminated water in low-lying residential areas [5].

Therefore, current waste management strategy is to encourage material recycling, energy recovery, and waste stabilization before landfilling. Solid waste landfilling, composting, recycling, and incineration are commonly 
used as methods of solid waste disposal or treatment. Currently landfilling in many places is a challenge in many areas, especially as landfill space is increasingly scarce.

The high water content of municipal solid waste can reduce the efficiency of energy recovery and beneficial utilization. To overcome this problem, there is an innovation in waste processing technology, one of which is the Bio-drying Process. Bio-drying technology, which aims to remove water through microbial activity, is considered a good solution to reduce the moisture content of wet organic wastewater. Bio-drying or biological drying is a bioconversion reactor from MechanicalBiological Treatment (MBT) which can be used as an alternative solution for mixed waste where the process will interact with microorganism activity [6].

The product produced from this bio-drying process is Refuse Derived Fuel (RDF) or Solid Recovered Fuel (SRF) where there is potential for thermal recovery due to the removal of large water content. By converting energy into waste, there are two objectives that can be obtained, namely as a supplement or substitute as a fuel in appropriate plants (grate or fluid bed plants, cement factories, etc.) and reducing landfill waste [7],[8]. This alternative mainly involves reducing the wastewater content, which increases the calorific value of the resulting product and reduces leachate production in the case of landfilling of waste substances if no further stabilization of the organic matter is applied [9].

\section{LITERATURE REVIEW}

Refuse fuel derived from a mechanical process with mixed raw materials for urban waste where noncombustible waste is set aside to produce a homogeneous mixture. In general, the RDF system has two functions, namely production and combustion. In the production process, recyclable waste such as glass and iron is set aside so that it does not enter the RDF production stage. Meanwhile, other types of waste such as organic waste, paper, and plastic can be used as raw materials and chopped to be reduced which is then processed to produce RDF products such as fluff or pellets. The most appropriate waste for RDF production is waste that has a high carbon content after being separated from recyclable waste. The RDF system is divided into two, namely: shred and burn system (in this system, there is no provision to set aside non-combustible waste), and simplified process system (this type of system is carried out by separating non-combustible, recyclable, and ferrous waste from mixed waste). Furthermore, the waste is put in the shedder to homogenize the size of the waste, which is $100-150 \mathrm{~mm}$ to optimize energy recovery during the combustion process [10]. RDF produces neutral CO2, and as an alternative energy [11]. Research result showed that RDF produced from municipal solid waste processing has a calorie value of $14,65-20.93 \mathrm{MJ} / \mathrm{kg}$ [12].
Other research result : In Indonesia, RDF calorie value has $12.5 \mathrm{MJ} / \mathrm{kg}$, moisture $<20 \%$, and size $<50 \mathrm{~mm}$ [13], Regarding Chaerul and Fakhrunnisa, the heat generated by the RDF material is the highest around $3578 \mathrm{kcal} / \mathrm{kg}$, with a moisture content value of $20-30 \%$ and an optimum time of 17-22 days [14]. RDF parameters that still do not meet international standards are ash content, fixed carbon, and organic carbon. The quality of RDF is strongly influenced by the composition of the feed. Although it cannot meet all the parameters as the international standard of RDF, the product can be used as additional fuel to replace coal or other fossil fuels for industrial activities [14]. RDF sustainability was analyzed using Integrated Sustainability Waste Management (ISWM). Below (table 1) is the ISWM framework referring to Nikhitul [15].

Table 1. RDF criteria

\begin{tabular}{|c|c|c|c|c|c|}
\hline Parameter & $\begin{array}{l}\text { Finlandia } \\
a\end{array}$ & Italia & $\begin{array}{l}\text { Great } \\
\text { Britain }\end{array}$ & $\begin{array}{l}\text { Indonesia } \\
c\end{array}$ & Thailand \\
\hline $\begin{array}{l}\text { Calorific } \\
\text { value } \\
(\mathrm{MJ} / \mathrm{kg})\end{array}$ & $13-16$ & 15 & 18.7 & 12.5 & N/A \\
\hline $\begin{array}{l}\text { Moisture } \\
\text { (\%wet) }\end{array}$ & $25-35$ & $\begin{array}{l}\max \\
25\end{array}$ & $7-28 \boldsymbol{b}$ & $<20$ & $<30$ \\
\hline $\begin{array}{l}\text { Ash } \\
\text { content } \\
\text { (\%wet) }\end{array}$ & $5-10$ & 20 & 12 & N/A & N/A \\
\hline size (mm) & N/A & N/A & N/A & $\leq 50$ & $<30$ \\
\hline
\end{tabular}

Environment \& Forestry Ministry

On bio-drying, this waste drying technique relies on the biological activity of microorganisms (bacteria and fungi) to reduce the water content by increasing the calorific value (increasing in the range of 30-40\%) waste with high moisture content can be transformed into solid fuels that can be used in the future come [16]. In contrast to composting, bio-drying takes about 2-3 weeks [17]. In addition, bio-drying helps to reduce the water content of urban waste and the organic degradation that occurs to a minimum so as to maintain the heating value. Whereas in composting, organic degradation is carried out as much as possible for full bio-stabilization which aims to produce humus to improve soil quality [18]. The advantage of the bio-drying process is that it reduces waste mass and emissions of $\mathrm{CH} 4, \mathrm{CO} 2, \mathrm{SO} 2, \mathrm{NOX}$, and dust emissions from landfill waste into the atmosphere [19]. On bio-drying process, measurements were made using a pilot scale bio-dryer that allows the recording of data as air flow, temperature (at the entrance, at the exit and inside the waste), and weight loss [8]. Other researcher said that the bio-drying process resulted in the weight of the mixed municipal solid waste substrate having been reduced by $33.94 \%$ in 20 days of reaction and the average moisture reduction of the matrix was $20.81 \%$ (reduced from the initial value of $61.25 \%$ to the final value of 48.5\%).[20] This study purposes on the sustainability of the potential of RDF as an alternative 
industrial fuel by paying attention to the aspects that influence it, namely the economic aspect by comparing the price of RDF with coal, the technological aspect by comparing the calorific value using bio-drying with minimal criteria, the environmental aspect by projecting Greenhouse Gas emissions (GHG) that can be avoided and social aspects (the perceptions of scavengers and looking for the right engagement approach). According to research, the unit price of ready-to-use RDF is IDR 293 thousand per ton [13]. Of course, this price is similar to the unit price of rice husks, but RDF has a higher calorie value than rice husks. Sustainability can only be achieved if all aspects are met.

\section{RESEARCH METHOD}

The research was conducted in Cilacap City, Central Java Province (Indonesia) from around October 2012 to July 2017 (part of feasibility study). The construction period for the RDF plant starts from August 2017 to October 2018. The data is part of a feasibility study collected from research results in other countries listed in journals, several universities in Indonesia, relevant agencies in Cilacap City, the condition of the research area (including the characteristics of scavengers) and several waste manufacturing companies. This research is focused on fuel for the cement industry because it is close to one of the largest cement factories in Indonesia (efficiency of transportation costs).

This study examines three main aspects, the calorific value of RDF, avoiding $\mathrm{CO} 2$ emissions by using RDF, and the inclusion of scavengers. The avoided GHG emissions are calculated based on the projected emissions that could be released if municipal solid waste were stockpiled (based on the volume of coal replaced as fuel, start on 2022) [21]. The perceptions and inclusiveness of scavengers were analyzed descriptively.

After delivery of fresh waste (approximately 120 tons of mixed municipal solid waste), a screening unit is used to categorize it by size in fractions $<150 \mathrm{~mm}$, and $<15 \mathrm{~mm}$. Waste fraction $<150 \mathrm{~mm}$ during experiment 1 and fraction $<15 \mathrm{~mm}$ during experiment 2 were subjected to landfill. Bio-drying cycle is valid for 21 days per cycle. This enables effective waste filtration for the separation of recyclable materials from high calorific value materials consisting of components of fine organic fractions.

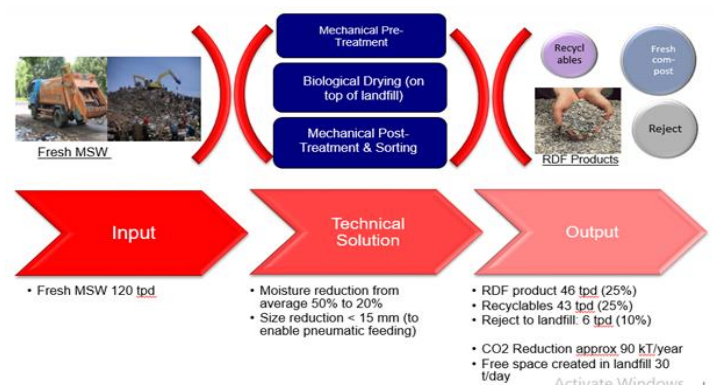

Figure 1 RDF process methodology

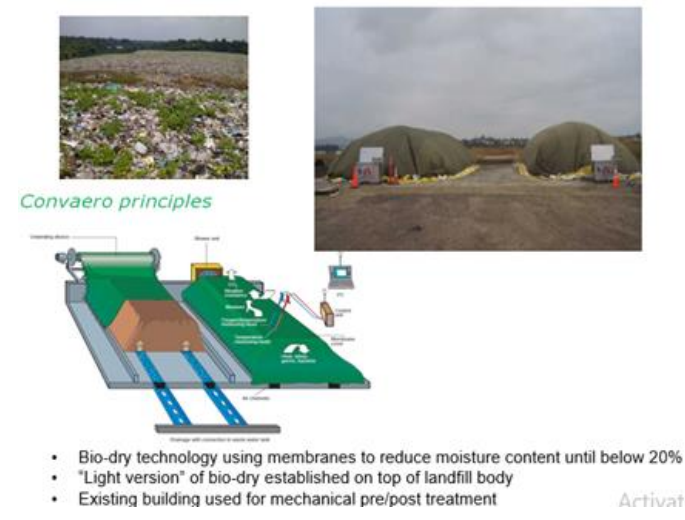

Figure 2 Bio-drying process (convaero system)

1 Bay bio-drying is capable of processing about 35 tons of fresh waste drying. This means that 1 bay of biodrying machine takes about 3 days to process 120 tons of fresh incoming waste.

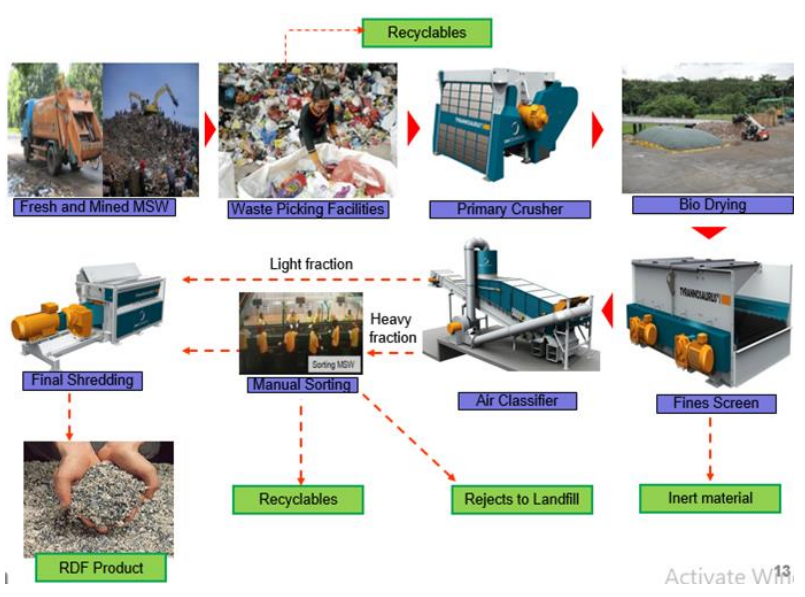

Figure 3 Detailed Technical Proposal

The RDF processing method uses the simplified process system method (see fig.1), while the bio-drying process uses a convaero system (see fig.2), and all equipment process can be seen in the detailed technical proposal (see fig.3). The reason for this research using the bio drying method is to reduce the amount of leachate produced in the waste treatment process (zero leached) [22].

\section{RESULT AND DISCUSSION}

This research investigated the effectiveness of biodrying to produce RDF to increase the calorific value of waste. The results of the material properties research are shown in table 2 (comparison before and after using biodrying). While the efficiency parameters after the feeding process in the kiln can be seen in table 3. This research also got reduced volume of landfill waste is 120 ton/day. 
Table 2. RDF Result

\begin{tabular}{|c|c|c|}
\hline Parameter & $\begin{array}{c}\text { Incoming } \\
\text { waste }\end{array}$ & Output \\
\hline $\begin{array}{c}\text { Calorific value, average } \\
(\mathrm{MJ} / \mathrm{kg})\end{array}$ & 2.97 & 14.55 \\
\hline Moisture, average (\%wet) & 59 & 22.45 \\
\hline Ash, average & 10 & 17.47 \\
\hline
\end{tabular}

From Table 2 it can be seen that the effect of drying the bio-drying system waste is very beneficial where the calorific value is almost $600 \%$ of calorific value of the incoming waste for processing. Table 3 also shows that the processing of RDF as an alternative fuel to replace coal is very significant which has the advantages of reducing urban waste accumulation. This shows that the circular economic and sustainability process occurs in this urban waste management.

Table 3. Feeding to kiln Criteria

\begin{tabular}{|c|c|c|}
\hline Parameter & $\begin{array}{l}\text { Before } \\
\text { feeding }\end{array}$ & $\begin{array}{l}\text { After } \\
\text { feeding }\end{array}$ \\
\hline Volume max (ton/days) & 120 & $\begin{array}{r}70 \\
(58 \%)\end{array}$ \\
\hline $\mathrm{CO} 2$ saving (ton) & N/A & 65.8 \\
\hline $\begin{array}{l}\text { Reduction Greenhouse Gas } \\
\text { emissions (GHG) tax (USD/day) }\end{array}$ & N/A & 0.35 \\
\hline $\begin{array}{l}\text { Clinker production average } \\
\text { (ton/day) }\end{array}$ & 213.18 & 216.38 \\
\hline Coal saving (USD/day) & N/A & 70 \\
\hline
\end{tabular}

Table 4. RDF, Rice Husk and Coal Criteria

\begin{tabular}{|c|c|c|c|}
\hline Parameter & RDF & $\begin{array}{c}\text { Rice } \\
\text { Husk }\end{array}$ & Coal \\
\hline $\begin{array}{c}\text { Calorific value, } \\
\text { average }(\mathrm{MJ} / \mathrm{kg})\end{array}$ & 14.55 & 10.05 & 18.21 \\
\hline $\begin{array}{c}\text { Moisture, average } \\
(\% \text { wet })\end{array}$ & 22.45 & 27 & 23 \\
\hline Ash, average & 17.47 & 18 & 7 \\
\hline
\end{tabular}

Table 4 shows that the RDF criteria as an alternative fuel (based on calorific value, moisture content and ash) are still superior to rice husks, and almost resemble coal criteria. For the social aspect, the scavengers can still work in this urban waste processing area with a total of 100 people.

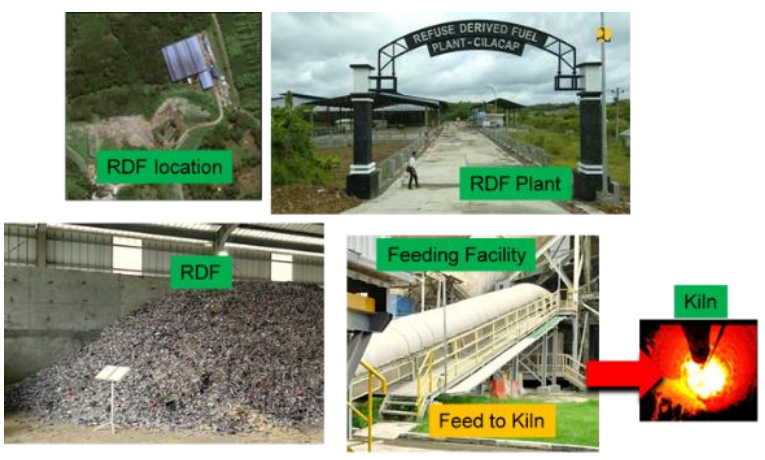

Figure 4 RDF Plant and Process situation

Figure 4 shows that until now the processing of urban waste into RDF to be used as an alternative to industrial fuel is still ongoing and there are no significant obstacles.

\section{CONCLUSIONS}

This study concludes that urban waste that is processed into RDF for alternative industrial fuels in Indonesia is highly recommended because it has many advantages, from the financial aspect, the price is in the range of rice husk prices; technical aspects, the calorific value of RDF is more than $14 \mathrm{MJ} / \mathrm{kg}$ so that it can be used as a substitute for coal fuel, and is environmentally friendly, which can avoid $\mathrm{CO} 2$ emissions of more than 65 tons per day. The social aspect must be considered, where the social inclusion of scavengers can be a solution for that. Technological aspects are also used in research so that the waste processing process is fast and controlled.

This research requires a large investment, so that further research should be carried out at a lower cost but provide maximum results. And it is also hoped that in the future the RDF system can be used for other industrial fuels such as power plant, textile industry and so on.

\section{ACKNOWLEDGMENT}

The pilot study and research was conducted at the location of a cement factory facility located in West Java (Indonesia). While the location of the implementation is in the province of Central Java (Indonesia). We would like to thank the support of several relevant agencies in the Central Java regional government, the central government of Indonesia, the Canadian government, several universities in Indonesia and one of the cement companies in Indonesia who have contributed to the supply, equipment, manpower, and laboratories needed. This research did not receive a special grant from any funding agency.

\section{REFERENCES}

[1] D. Q. Zhang, P. J. He, and L. M. Shao, "Sorting efficiency and combustion properties of municipal solid waste during bio-drying," Waste Manag., vol. 29, no. 11, pp. 2816-2823, 2009, doi: 10.1016/j.wasman.2009.06.024. 
[2] SIPSN, "Capaian Kinerja Pengelolaan Sampah," 2021. [Online]. Available: https://sipsn.menlhk.go.id/sipsn/.

[3] L. Siami, T. Sotiyorini, and N. Janah, "Municipal Solid Waste Quantification And Characterization In Banyuwangi, Indonesia," vol. 2, no. 2, pp. 189-200, 2019.

[4] M. Samsuri and L. Hikmat, "Model Pengelolaan Sampah Perkotaan (Survey Pada Pengelolaan Persampahan Kota Bogor),' J. Visionida, vol. 5, no. 2, p. 54, 2019.

[5] World Bank Indonesia, "Indonesia Environment Monitor 2003," 2003.Berlin, Heidelberg, 2011, pp. 53-113. DOI: https://doi.org/10.1007/978-3-64221455-4_3

[6] Choi, T. L. Richard, and H. Ahn, "Composting High Moisture Materials : Biodrying Poultry Manure in a Sequentially Fed Reactor,” no. July, 2001.

[7] F. Adani, L. Scatigna, and P. Genevini, "Biostabilization of mechanically separated municipal solid waste fraction," pp. 471-477, 2001.

[8] P. Taylor et al., "Lower Heating Value Dynamics during Municipal Solid Waste Bio-Drying," no. March 2013, pp. 37-41, 2010.

[9] S. Hemidat, M. Saidan, S. Al-Zu'bi, M. Irshidat, A. Nassour, and M. Nelles, "Potential utilization of RDF as an alternative fuel to be used in cement industry in Jordan," Sustain., vol. 11, no. 20, 2019.

[10] M. Chaerul and A. K. Wardhani, "Jurnal Presipitasi Refuse Derived Fuel ( RDF ) dari Sampah Perkotaan dengan Proses Biodrying: Review,” J. Presipitasi, vol. 17, no. 1, pp. 62-74, 2020.

[11] C. A. Velis, P. J. Longhurst, G. H. Drew, R. Smith, and S. J. T. Pollard, "Bioresource Technology Biodrying for mechanical - biological treatment of wastes: A review of process science and engineering," Bioresour. Technol., vol. 100, no. 11, pp. 2747-2761, 2009.

[12] K. K. Ummatin, A. Hanni, and Q. A. M. O. Arifianti, "Quantity and quality analysis of RDF ( refused derived fuel ) as an alternative fuel substitution for coal in a cement industry Quantity and Quality Analysis of RDF ( Refused Derived Fuel ) as an Alternative Fuel Substitution for Coal in a Cement Industry," vol. 030114, no. April, 2019.

[13] P. Dianda and E. Munawar, "Sustainability of Refuse Derived Fuel Potential from Municipal Solid Waste for Cement's Alternative Fuel in Indonesia ( A Case at Jeruklegi Landfill, in Cilacap ) Sustainability of Refuse Derived Fuel Potential from Municipal Solid Waste for Cement ' s," IOP Conf. Ser. Earth Environ. Sci. 159 012027, 2018.

[14] M. Chaerul and A. Fakhrunnisa, "Refuse Derived Fuel Production through Biodrying Process (Case study: Solid Waste from Canteens)," J. Bahan Alam Terbarukan, vol. 9, no. 1, pp. 69-80, 2020.

[15] J. Nithikul, "Potential of Refuse Derived Fuel Production," 2007.

[16] F. Adani, D. Baido, E. Calcaterra, and P. Genevini, "The influence of biomass temperature on biostabilization - biodrying of municipal solid waste," vol. 83, pp. 173-179, 2002.

[17] S. Sadaka, K. Vandevender, T. Costello, and M. Sharara, "Partial Composting for Biodrying Organic Materials," 2010.

[18] B. Yang, Z. Hao, and D. Jahng, "Advances in biodrying technologies for converting organic wastes into solid fuel," no. May 2017, 2019.

[19] A. . Tom, A. Haridas, and R. Pawels, "Biodrying Process Efficiency: Significance of Reactor Matrix Height," Procedia Technol. 25, 130-137., 2016.

[20] A. P. Tom, R. Pawels, and A. Haridas, "Biodrying process : A sustainable technology for treatment of municipal solid waste with high moisture content," WASTE Manag., pp. 1-9, 2016.

[21] DPR RI, RUU KUP 2021 - Pajak Karbon. 2021.

[22] P. Purwono, M. Hadiwidodo, and A. Rezagama, "Penerapan Teknologi Biodrying Dalam Pengolahan Sampah High Water Content Menuju Zero Leachate," J. Presipitasi Media Komun. dan Pengemb. Tek. Lingkung., vol. 13, no. 2, p. 75, 2016, doi: 10.14710/presipitasi.v13i2.75-80. 